\title{
Governance Research of Chinese Rural Finance Exclusion Based on Peasant Survey*
}

\author{
Huixia Cheng, Wentai Wu \\ School of Government, Beijing Normal University, Beijing, China \\ Email: chx99@126.com
}

Received 17 June 2014; revised 15 July 2014; accepted 20 August 2014

Copyright (C) 2014 by authors and Scientific Research Publishing Inc.

This work is licensed under the Creative Commons Attribution International License (CC BY). http://creativecommons.org/licenses/by/4.0/

CC) (†) Open Access

\begin{abstract}
The construction of people's livelihood in rural areas not only needs to meet their basic requirements such as elders' care, medical care, and insurance and so on, but also needs to encourage people living in rural areas and make them have confidence to earn a better live through the improvement of self-development ability. "Insufficiency of self-development ability" and "the lack of opportunity of development" are two of the most important barricades, which interact rural "finance exclusion" as both cause and effect and exert reciprocal intensification as well. The interviewing result from the 1938 random samples of local citizens living in villages and towns, which belong to 5 provinces and 26 counties and cities, shows that "lack of funds" is the hugest barricade that prevents peasants improving their self-development ability. The situation is mostly caused by "non-physical finance exclusion". To govern this situation, the diversity of rural finance requirements and financial ecology cannot be separated and combination usage of different kinds of governance tools is needed.
\end{abstract}

\section{Keywords}

Rural Finance Exclusion, Non-Physical Finance Exclusion, Self-Development Ability, Governance Policy

\section{Introduction}

To ensure the simultaneous growth of people's livelihood and economy and to avoid the "the trap of lack of people's livelihood” should be the key points of construction of rural people's livelihood. The historical proof of East Asian countries' economic and social development illustrates that construction of people's livelihood, which

\footnotetext{
${ }^{*}$ This research is sponsored by Chinese National Social Science Fund (10DGL057).
} 
can minimize the social polarization and ensure social justice, is the prerequisite and fundament of avoiding social disorder [1]. People's livelihood and the construction process of it are often thought as the providence of basic public products, namely elders' care, medical care, employment and insurance. However, as far as peasants and other disadvantaged groups are concerned, the essence of construction of people's livelihood should be more than what's mentioned above. Its major theme is to encourage the peasants that they can have a better life in the future with their effort on the improvement of self-development ability. The interviewing result from the 1938 random samples of local citizens living in villages and towns, which belong to 5 provinces and 26 counties and cities, shows that "lack of funds" is the hugest barricade that prevents peasants improving their self-development ability. The situation is mostly caused by "non-physical finance exclusion”. To govern this situation, the diversity of rural finance requirement and financial ecology cannot be separated; combination usage of different kinds of governance tools is needed.

\section{Concept and Review of Literature}

Research on "the relationship between financial development and economic growth" reveals that the efficient allocation of financial resources has a promoting effect on the economic growth. Pushing economy via adding financial supplying has been a guiding thought for the elimination of poverty in backward areas since the 1960s. Policy-oriented finance, cooperative finance and micro finance is flourishing in the backward areas, especially in rural areas. Measured by indexes like "number of formal rural financial organizations", "number of branches per ten thousand peasants", "number of bank faculties per ten thousand peasants", rural finance has developed in a great deal. However, rural economic growth is not very significant.

Take China as an example: increasing rural financial supplying is the main theme of rural financial reforming between 1978 and 2011. The number of villages and towns with completely no finance organization or service has decreased rapidly, the number of finance service and bank faculties has increased from 12.48 in 2006 to 19.62 in 2011, however, at the same time income distance between cities and villages is getting larger and larger. 128 million people who are suffering poverty are mostly in rural areas, accounting for the 13.4 percent of total population in rural areas. That is to say, finance does not "engine” economy significantly in rural areas. Due to the incompletion and division of rural finance market, a large number of peasants and micro enterprises are excluded from the process of economic growth. The phenomenon is called "Finance Exclusion” [2]-[4].

Finance exclusion means that through formal access, some people, enterprises, business groups and districts cannot get necessary finance service such as savings and loans. What is usually understood is finance exclusion is a kind of phenomenon that it is difficult for some certain groups to get low-cost money from major formal finance organizations as well as they cannot get any more finance products or service besides saving, so that they have quite trouble in using necessarily required finance products or service in both social life and economic process [5]-[8]. It is the result of the natural choice finance organizations make after they balance cost, risk and profit, which actually reflects social characteristics of excluded groups such as social status, income level, education level, settlement location, age and gender, marriage condition, ethnic groups and so on. From these indexes, finance exclusion is a derivative and measuring dimension of social exclusion. They interact with each other both as cause and effect as well as reciprocal strengthening elements. Thusly, the disadvantage groups are alienated and different areas would have differently unbalanced development levels. Due to its belonging to the archetypal field of market failure, out of question, it is governments' duty to make sure citizens can get finance service fairly [8].

UK Finance Service Authority once built linear regression model by using “Index of Multiple Deprivation” as the dependent variable, fixed variables which are related with finance exclusion by using stepwise regression, calculated index of finance exclusion, and then made strategies to govern finance exclusion [7]. However, this method cannot be universalized because of the difficulty of getting required data. Brought forth by Kempson \& Whyley (1999), six dimension model of finance exclusion is widely accepted. Thusly, these six dimensions, namely "Physical Exclusion”, “Access Exclusion”, “Condition Exclusion”, "Price Exclusion”, “Marketing Exclusion” and "Self-Exclusion”, are often used as variables in substitution measurement [6].

Based on that, Tian (2008) and Wang (2010, 2011) measured the situation of finance exclusion, the dilemma of rural finance exclusion and the area differentiation in 31 provinces in China. They found out that geographic characteristics, the development level of regional economy are the two most related variables with finance exclusion [9]-[11]. Hu (2012) used principal component analysis and comprehensively calculated rural finance exclusion levels of 29 provinces in China from 1995 to 2009. His result says that the level of finance exclusion is 
the most severe in Guizhou, Qinghai, Yunnan and Guangxi, while in Tianjin, Liaoning, Jilin, Shanghai and Beijing, rural finance exclusion is the least severe. Levels of finance exclusion in other provinces are among the medium, for many years ranks of Guangdong and Fujian are only behind rank of Gansu. The rankings have a relatively large fluctuation and have no significant relationship with regional economic development [12].

However, this kind of measuring method is not generally agreed. For instance, Li and Jia (2012) think that the index system built by Wang cannot accurately reflect the essences of the six dimensions. Borrowing idea from "Human Development Index" brought forth by the United Nations Development Program, they built measure model of finance exclusion from four dimensions, which are the depth, accessibility, usability and affordability of finance service. After measuring and analyzing, they found out that in the year of 2010 most provinces had a generally serious condition of finance exclusion and that there is a huge difference among levels of finance exclusion in different provinces: four municipalities and Guangdong Province have a relatively low finance exclusion level $(\leq 0.5)$, areas in western China have a rather serious level of finance exclusion $(\geq 0.8)$, while central areas have a relatively high level of finance exclusion (0.5 0.8) [13].

In spite of using different indexes, all those methods mentioned above have a similar conclusion: finance exclusion in rural areas are more serious than that in urban areas; rural finance exclusion in western China is more serious than that in eastern China; there are no coherent measuring result among all the provinces and the result shows a tendency of fluctuation.

\section{Peasant Survey about the Rural Financial Exclusion}

Currently existing research on rural finance exclusion measure model mostly use the official statistics, such as GDP per capita, number of banking account, balance of savings and loans, number of branches per ten thousand peasants. These statistics neglect the effect that peasants' improvement of self-development and finance demand exerts on rural finance exclusion. To solve the consequence caused by the effect, our research uses the prevalent "Six Dimensions Model of Finance Exclusion" as a reference, we take a survey of new type rural finance organization experimented by CBRC (China Bank Regulatory Commission) in Jilin, Hubei, Sichuan, Gansu and Qinghai. By using structural questionnaire and open-end interviewing, we investigate 1938 random samplings (picking out those with no effectiveness) of peasants in areas covered by all the 26 new type rural finance organizations from August 8th to August 23th in the summer of 2012 ${ }^{1}$.

According to the survey, income sources of peasants include "Business", "Salary”, "Agricultural Production”, "Products Processing and Poultry". Among those, "Business" is the most important income source (Table 1). They all have quite a strong inclination to improving the quality of their life, but this motivation meets the difficulty of "Lack of fund" (Table 2). Our conclusion is basically coherent with the conclusion driven by Liu (2008) [14].

New type rural finance organzitions have offered peasants more mortgage accesses since 2006. Our survey shows that the importance of "relatives and friends" has changed when cizitens in rural areas want to borrow money: In Jilin and Hubei, "relatives and friends" are the easiest to borrow money from; while in Qinghai and Gansu, "relatives and friends" are as important as "rural credit coorpratives"; Peasants in Sichuan only rank "relatives and friends" as the 3rd important access to borrowing money. Rural credit coopratives are very popular among peasants in Qinghai and Gansu while in "village banks" are most accepted by peasants in Sichuan Province (Table 3). For a general overview, peasants investigated in all provinces except Hubei think that "relatives and friends", "rurral credit cooproratives" and "village banks" are easiest three accesses to borrowing money. The acceptance order of new type rural finance organization is "village bank", "mutual fund agency" and "small-amount loan company" (Figure 1).

On one hand, this situation indicates that traditional social structure and ethical relationship has changed greatly along with the process of urbanization, which has also exerted a huge influence on the peasants' traditional savings and loans. On the other hand, it also shows that compared with other rural finance organizations, business of new type rural organizations in county areas is more easily accepted by peasants, which can be regarded as the positive effect on incremental reform (Table 4).

\footnotetext{
${ }^{1}$ Number of effective questionnaire in Jilin Province is 372, including Dongfeng in Liaoyuan City, Panshi in Panshi City, Zhenlai in Baishi City, Qianguo in Songyuan City, Lishu in Siping City. Number of effective questionnaire in Qinghai and Gansu Province is 329, including Ledu in Xining City, Datong in Xining City, Jingtai in Baiyin City, Huining in Baiyin City, Jingchuan in Pingliang City, Xifeng in Qingyang City. Number of effective questionnaire in Sichuan is 847, including Yilong in Nanchong City, Shizhong in Guangyuan City, Cangxi, Beichuan, Dayi, Qionglai and Pengzhou. Number of effective questionnaire in Hubei is 190, sampling from townships and villages around Hanchuan city, Xiantao city, Suizhou city and Jiayu county.
} 
Table 1. Income structures of investigated peasants in five provinces.

\begin{tabular}{ccccc}
\hline & Jilin & Sichuan & Qinghai \& Gansu & Hubei \\
\hline Agricultural Production & 329 & 82 & 273 & 111 \\
Poultry & 125 & 85 & 22 & 45 \\
Products Processing & 41 & 68 & 3 & 7 \\
Business & 70 & 504 & 228 & 18 \\
Salary & 107 & 353 & 254 & 88 \\
\hline
\end{tabular}

Table 2. Barriers for peasants' becoming rich in five provinces.

\begin{tabular}{ccccc}
\hline & Jilin & Sichuan & Qinghai \& Gansu & 487 \\
\hline Lack of Fund & 201 & 463 & 109 & 74 \\
Lack of Knowledge about Investment & 81 & 166 & 138 \\
Lack of Skills of Making Money & 149 & 209 & 268 & 75 \\
Lack of Market Information & 43 & 69 & 47 \\
Lack of Government Support & 53 & 84 & 30 \\
Others & 42 & & 25 \\
\hline
\end{tabular}

Table 3. A provincial comparison of easiest access to loans (\%).

\begin{tabular}{|c|c|c|c|c|}
\hline & Jilin & Sichuan & Qinghai \& Gansu & Hubei \\
\hline Relatives \& Friends & 35 & 14 & 30 & 70 \\
\hline Rural Credit Cooperatives & 17 & 25 & 30 & 4 \\
\hline State-Owned Banks & 9 & 7 & 6 & 18 \\
\hline Rural Commercial Banks & 18 & 10 & 3 & 0 \\
\hline Village Banks & 18 & 30 & 9 & 7 \\
\hline Mutual Fund Agencies & 3 & 8 & 22 & 0 \\
\hline Small-Amount Loan Company & 0 & 6 & 0 & 1 \\
\hline Usurious Loan & 0 & 0 & 0 & 0 \\
\hline
\end{tabular}

Table 4. The increasing tendency of village banks, small-amount, mutual fund agency and others.

\begin{tabular}{ccccc}
\hline & 2008 & 2009 & 2010 & 2011 \\
\hline Loans to Farmers & 13.98 & 66 & 207.4 & 313.8 \\
Loans to SMEs & 18.8 & 91 & 620 & 600.8 \\
Agriculture-Related Loans & 34.2 & 181 & 1316 \\
\hline
\end{tabular}

Data from: Annals of the year of 2011 of CBRC.

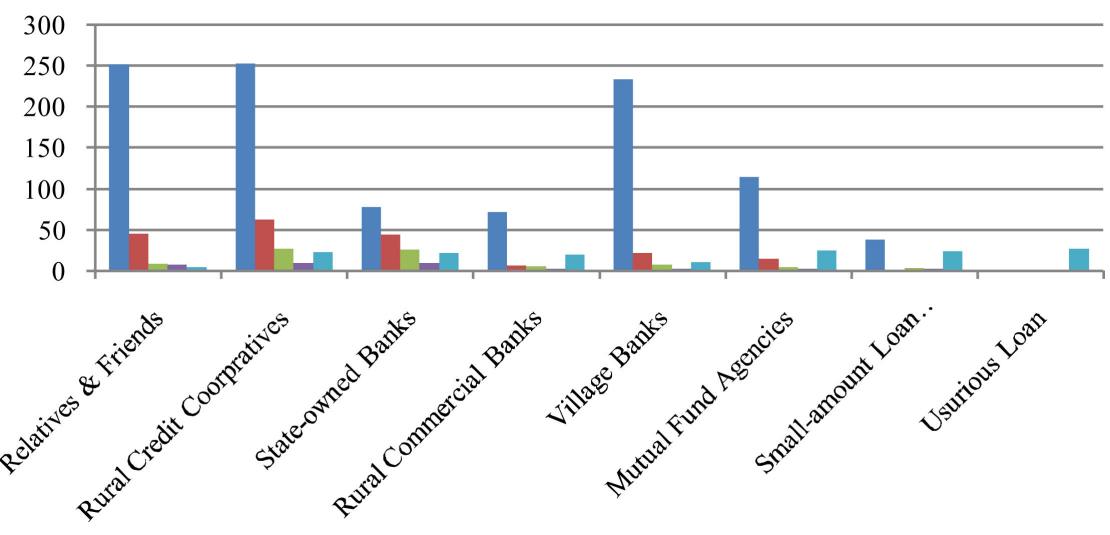

Figure 1. Easiest access to borrowing money: Provincial difference removed. 
The change of finance demand caused by peasants' pursuit for development and the effect of incremental reform of rural finance illustrates that physical rural finance exclusion any is not significant longer. The improvement of physical exclusion also drives the weakening of "self-exclusion". According to the survey, 59 percent of peasants have the experience of borrowing money, 21 percent of whom say that rural finance organization has offered extra help besides money, such as techniques and skills to make money, knowledge of investing and financing, spreading peasants beneficial policy (Figure 2). They also think that the help mentioned above has a positive effect on the increasing of family income, the relieving of lack of money, the change of thoughts and behavior. Generally speaking, $63 \%$ of peasants on the survey think that rural finance organization has improved local economic circumstances, especially the convenience of capital accumulation and allocation (Table 5).

However, during the survey, nearly all of the peasants hold the point that there is severe exclusion in the process of finance service offered by rural finance organization. Take new type rural finance organization as an example. Interviewees think that there exist some problems in village bank, small-amount loan companies and mutual fund agencies. Frequently voted problems are the high lending rate, the small amount of credit, strict limitations, complicated procedures, short deadline of paying back and "other problems" (Table 6).

Comparatively speaking, "other problems" includes more information about finance exclusion. This question is open-end; interviewees can express whatever they want. Accord to the statistical result of Spss 11.0, peasants in Jilin and Hubei emphasize much on the importance of "Guanxi"; interviewees in Qinghai and Gansu have a variety of arguments, including "unknown/unfamiliar", "depends on relationship/need to bribe/only available for those who are powerful or rich", "lack of money in finance organizations”, “cannot find a guarantor", "high-
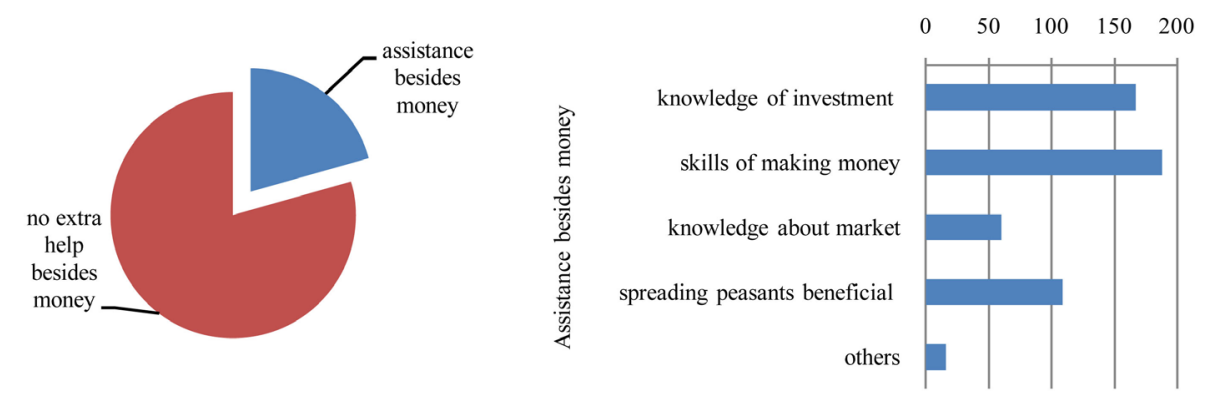

Figure 2. Assistance besides money from rural finance organizations.

Table 5. Peasants’ attitude towards local economic circumstances.

\begin{tabular}{|c|c|c|c|c|}
\hline & Hubei & Jilin & Qinghai \& Gansu & Sichuan \\
\hline Convenient Payment and Settlement & 25 & 140 & 20 & 161 \\
\hline Convenient Capital Accumulation and Allocation & 56 & 155 & 261 & 436 \\
\hline Diversification of Risk & 6 & 62 & 11 & 20 \\
\hline Investment Attraction Improved & 2 & 42 & 38 & 78 \\
\hline Others & 1 & 7 & 30 & 14 \\
\hline
\end{tabular}

Table 6. Frequently mentioned problems of rural finance service by interviewees.

\begin{tabular}{|c|c|c|c|c|}
\hline & Hubei & Jilin & Qinghai \& Gansu & Sichuan \\
\hline Loan Commitment & 12 & 81 & 69 & 221 \\
\hline Short Duration of Repayment & 14 & 30 & 39 & 125 \\
\hline Mortgage Notarization Fee & 79 & 33 & 13 & 163 \\
\hline Low Efficiency of the Loan Approval & 9 & 23 & 12 & 63 \\
\hline High Interest Rates & 15 & 80 & 63 & 241 \\
\hline Loan Procedures Cumbersome & 39 & 37 & 104 & 112 \\
\hline Single Financial Services & 12 & 14 & 12 & 79 \\
\hline Others & 36 & 132 & 54 & 244 \\
\hline
\end{tabular}


level requirement”, “terrible service attitude”, “inconvenient”; peasants in Sichuan rank "unknown”, “need an association”, “rake-off”, "low saving interest rate”, “strict requirement”, "lack of publicity”, “always lack of money" as the most serious problems.

After merging similar terms and removing the difference among different provinces, most frequently voted problems of new type rural finance organization during the process of running are "Guanxi”, "rake-off”, "unfamiliar”, "bad service attitude”, “high price”, “unfamiliar”, “strict limitations”, “distrust”, “inconvenient”, among which "Guanxi”, "rake-off”, "unfamiliar”, "high price” are the most serious. Because most peasants calculate "rakeoff” as a kind of cost, mainly existing problems of new type rural finance organizations are "Guanxi”, "unfamiliar", "rake-off/bribe”.

To sum up, rural areas in China, including backward rural areas in central and western China, mostly common regional finance exclusion are access exclusion, condition exclusion, price exclusion, marketing exclusion and other kinds of "non-physical exclusion”. To emphasize, factors like "Guanxi/background”, "rake-off/bribe” may intensify these kinds of “non-physical exclusion” and exert a negative influence on peasants' accessibility of loans and other finance service.

\section{Governance Discussion of Rural Finance Exclusion: To Improve Peasants' Self-Development Ability}

In China, villages, where once were described with words like "localism”, “acquaintance society”, are eliminating because of urbanization, industrialization and equalization of fundamental public service in rural and urban areas [15]. Peasants, one large group who had been excluded from the social security system, begin to enjoy public service, such as education, employment, medical and elders' care, disaster and emergency relief and other social reliefs. The dramatic improvement of “social exclusion” has offered peasants unprecedented opportunities to pursue self-development. Nevertheless, in rural areas, infrastructure, equipment, technology, education level, income access and financial attainment are all far behind those in cities and towns. Consequently, confidence and ability of peasants’ pursuing self-development are held back, and “non-physical exclusion” makes this situation worse.

To develop rural finance does not simply mean to increase finance organizations, it also includes the development of adaptability, accessibility and affordability of rural finance service. The governance of finance exclusion should not only put emphasis on the elimination of finance vacant counties and villages but also the improvement or the elimination of "non-physical exclusion" that peasants are suffering from at present. Lots of papers on finance exclusion treat sex, age, marriage, ethnicity, property, vocation, education level, settling areas and popularity of internet as exclusion factors that peasants, low-income groups and other disadvantaged groups suffer from [16]-[23]. However, in terms of people's livelihood, these factors mentioned above should not be government's excuse for letting peasants and low-income groups stay deprived of finance service. Only on the conditions that peasants have the ability of self-development, can government's investment in infrastructure have a positively increasing effectiveness.

Therefore, as a technical thesis, "governance of non-physical financial exclusion” should regard the satisfaction of peasants' self-development ability as its both prerequisite and purpose, choose governance tool with the concern of peasants' finance demand. The value of that should be sharing, coordinating, harmony, justice, poverty alleviation.

If given a deep look from the structure of reciprocal effect between financial and economic growth, the non-physical characteristics of rural finance exclusion in China shows that the development of rural finance has entered the period of "demand following” when traits of rural finance system should be "following” and "adapting”. Thusly, governance of non-physical financial exclusion take comprehensive account of rural finance ecology, efficiency of rural finance system, finance sustainability of rural finance organization, justice of finance service and important factors.

Random samplings from five provinces show that peasants' funding demand has gradually changed from small-amount used to meet an emergency to large-amount used to create more fortune, from agricultural production to entrepreneurship (Table 7). "More than ten thousand yuan” ranks the highest in the loan-amount list, only superior to "three to five thousand yuan". There are also many interviewees marking the choice of "one to three thousand yuan" and "five to seven thousand yuan".

According to this result, we can safely draw a conclusion that there exists a difference of financial demand 
Table 7. Uses of loans to farmers (\%).

\begin{tabular}{|c|c|c|c|c|}
\hline & Hubei & Jilin & Qinghai \& Gansu & Sichuan \\
\hline Agricultural Production & 2 & 2 & 19 & 20 \\
\hline Investment & 4 & 4 & 2 & 8 \\
\hline Business & 2 & 1 & 31 & 38 \\
\hline Consuming & 1 & 2 & 5 & 4 \\
\hline Education & 44 & 47 & 13 & 1 \\
\hline Medical Service & 7 & 16 & 7 & 3 \\
\hline Residential Construction & 14 & 0 & 22 & 24 \\
\hline Others & 26 & 28 & 2 & 1 \\
\hline
\end{tabular}

among peasants who have different income levels. Consequently, a variety of financial supplying types and levels are necessary (Chart 1). It is the natural result of growth of rural economy as well as the evolution of rural finance ecology.

After sustainable growth, the per-capita net income of rural residents has reached $¥ 7917$ in 2012 . Most of rural residents have gone out of poverty completely and begin to demand higher level of finance service. At the same time the relationship between rural finance development and economic growth has changed. The increment of range of rural economic output becomes the force which drives the expansion of "added value of finance”.

Train of thoughts about governance of rural finance exclusion should be adjusted as well. Besides to broaden finance service access and solve the problem of physical finance exclusion, it is also quite essential to differentiate the kind of finance exclusion which low-income peasants have to face from the kind of finance exclusion which high-income peasants meet. The experience of governance finance exclusion in developed countries, such as USA and UK, can be learned by China.

Finance exclusion in UK mainly includes physical exclusion and complete exclusion of low-income groups. To govern the former exclusion, the UK government has tried to combine the partnership of commercial banks, post offices, credit cooperatives and NPOs as well as tried to broaden finance service access. It also tries to solve the paradox between commercial banks’ closing branches because of lack of profits and local residents' demand for access to fundamental bank service in remote and backward regions. To control the latter exclusion, the UK government provides money to develop cooperatives and help the poor people to meet the basic requirement of finance service. Specifically, what has been implemented by UK government includes: 1) the government has defined cooperatives as organizations mainly providing service to the backward communities. As a consequence, cooperatives would become the important source for low-income groups to enjoy low-cost credit and finance services. HM Treasury also sets up “cooperative-centered service of organization” to support the development of cooperatives; 2) The government founds "Social Fund" and "Trust Fund for Children" to help the poor people to accumulate their fortune so that they can meet the basic requirement of finance service; 3) To encourage people to deposit, the UK government has provided different kinds of financial information and financial education, helped the poor people to choose appropriate ways of saving money. Due to the encouragement of all the policy above, cooperatives from place to place enacted specific running strategies aim at poor groups. They encourage the poor to deposit and make "whether have small-amount savings" as the basic requirement of getting other kinds of finance service.

Finance exclusion in America is more complicated due to difference of sex, ethnicity, religion, region and income. The federal government intervenes much more strongly: 1) In order to prevent commercial banks from closing branches and divisions in low-income communities, "the Community Refunding Act(CRA)" defines "provide loans in low-income communities" as one standard of ranking banking business; 2) With the increasing of "finance supermarket", the founding "community bank", the promotion of combination of post offices and NPOs, the government tries to eliminate physical exclusion of the disadvantaged people. The US government sets up the upper limit of service prices through the accesses mentioned above, lowers the cost of replaceable finance service, and relieves access exclusion and marketing exclusion; 3) The government directly gives the poor people finance assistance so that they are able to open an account and get basic finance services. Marketing exclusion and condition exclusion can also be avoided in this way; 4) The US government encourages finance organizations to create new types of finance service or finance goods which are more suitable to the disadvan- 
Chart 1. Type of peasants (income), characteristics, finance demand and suitable finance supply.

\begin{tabular}{|c|c|c|c|}
\hline Type of Peasants & Characteristics & Finance Demand & Suitable Finance Supply \\
\hline $\begin{array}{c}\leq ¥ 1500 \\
\text { severely poor }\end{array}$ & $\begin{array}{ll}\text { - } & \text { no saving; } \\
\text { - } & \text { cannot work; } \\
\text { - } & \text { lack of labor; } \\
\text { - } & \text { basic ord ogriculture; } \\
& \text { production. }\end{array}$ & $\begin{array}{l}\text { - } \quad \text { need to be covered by social } \\
\text { insurance system; } \\
\text { - } \quad \text { need government's direct } \\
\text { subsidies instead of loans. }\end{array}$ & $\begin{array}{l}\text { - mainly supplied by government, } \\
\text { NPO finance supply is also } \\
\text { needed; } \\
\text { - } \quad \text { encourage them to save money; } \\
\text { help them to meet the basic } \\
\text { requirement of finance service; } \\
\text { - } \quad \text { spread financial knowledge and } \\
\text { information. }\end{array}$ \\
\hline $\begin{array}{c}\text { About } ¥ 3000 \\
\text { barely out of } \\
\text { poverty }\end{array}$ & $\begin{array}{l}\text { - } \\
\text { ample; } \\
\text { - have the ability to work } \\
\text { or run a business; } \\
\text { - enough labor; self-sufficiency; } \\
\text { - lack of necessary fund, means } \\
\text { of production or technique, skill; } \\
\text { - low education level. }\end{array}$ & $\begin{array}{l}\text { - have difficulty in offering } \\
\text { mortgage; } \\
\text { - } \quad \text { weak ability of preventing risk; } \\
\text { get rid of poverty completely } \\
\text { only by themselves; } \\
\text { be covered by social insurance } \\
\text { system and government's } \\
\text { direct subsidies and } \\
\text { poverty-alleviating loans. }\end{array}$ & $\begin{array}{l}\text { small amount and low interest } \\
\text { rate( } \leq 6 \% \text { per annual) or free of } \\
\text { interest loans; } \\
\text { mainly supplied by government, } \\
\text { policy-related finance or MIF } \\
\text { organizations; } \\
\text { Government's permission is } \\
\text { needed if commercial banks want } \\
\text { to participate in the name of CSR. }\end{array}$ \\
\hline $\begin{array}{l}¥ 5000 \text { - ¥6000 } \\
\text { completely out } \\
\text { of poverty }\end{array}$ & $\begin{array}{l}\text { - } \quad \text { some savings; } \\
\text { high ability of production; } \\
\text { sustainably undertake } \\
\text { specialized division of labor; } \\
\text { - } \quad \text { have knowledge and skill; } \\
\text { run large-scaled and profitable } \\
\text { business, often crop farming and } \\
\text { cultivation; } \\
\text { - } \quad \text { or work in big cities, drive a } \\
\text { transporting vehicle, undertake } \\
\text { construction program... } \\
\text { - } \\
\text { stable income. }\end{array}$ & $\begin{array}{l}\text { - } \quad \text { willingness and capability to } \\
\text { expand their business or } \\
\text { production or business; } \\
\text { demand for commercial loans; } \\
\text { - acceptable for high price loans } \\
\text { (10\% - 20\% annually); } \\
\text { demand for consumptive loans, } \\
\text { capital purchasing and other } \\
\text { kinds of finance service. }\end{array}$ & $\begin{array}{l}\text { have the demand for loans and } \\
\text { other kinds of finance service } \\
\text { provided by commercial and } \\
\text { policy-related rural finance } \\
\text { organizations which have to be } \\
\text { good at risk identification and } \\
\text { sufficient money; } \\
\text { the amount, requirement, interest } \\
\text { rate and ways to payback need to } \\
\text { be different because of diversity of } \\
\text { customers. }\end{array}$ \\
\hline $\begin{array}{l}\geq ¥ 10,000, \\
\text { rich and high } \\
\text { production }\end{array}$ & $\begin{array}{l}\text { - lots of savings; } \\
\text { - high level of education } \\
\text { - a strong ability or skill of } \\
\text { specialized production; } \\
\text { - productive efficiency has } \\
\text { increased with the method of } \\
\text { "cooperatives" and "company } \\
\text { \& peasant”. }\end{array}$ & $\begin{array}{l}\text { - demand for savings; } \\
\text { demand for large-amount } \\
\text { mercantile and consumptive } \\
\text { loans; } \\
\text { capital purchasing consultation } \\
\text { and other kinds of finance } \\
\text { service; } \\
\text { loan rate ( } 6 \% \sim 10 \% \text { annually) } \\
\text { can be relatively low because } \\
\text { of the abundance and high } \\
\text { pledge. }\end{array}$ & $\begin{array}{l}\text { It is advisable for them to be } \\
\text { supplied by commercial finance } \\
\text { organizations which have lots of } \\
\text { divisions and branches, large } \\
\text { amount of capital, a high level } \\
\text { of risk management. }\end{array}$ \\
\hline
\end{tabular}

taged people. It also tries to find ways to help them meet the demand of loans and relieve marketing exclusion.

To sum up, government in UK and US played a significantly important role in the governance of finance exclusion. The influence of government's direct providence, regulation and other classic governance tools can never be underestimated, though plenty of tools of New Public Management are used, such as franchise operation, the construction of partnership between public and private sectors, the encouraging policy for commercial finance organizations to serve for the disadvantaged people.

Enlightening from the experiences above, we can safely draw a conclusion that the goal of governing finance exclusion should be the eliminating of poverty and the cultivation of peasants' confidence of pursuing self-development. After finishing the construction of social security system and living subsidy system with direct transfer payment, governments can make peasants and low-income groups get basic finance services by helping them to open accounts, encouraging small-amount savings, popularizing finance knowledge and so on. In order to avoid the effect of "guanxi/background", "rake-off/bribe" and other negatively influential factors, governments can also set up policy-related finance and MIF organizations which provide low interest rate or free of interest loans. The China government should enact and implement policies to encourage commercial finance organization to 
provide finance service for low-income peasants. It is even advisable for the government to directly borrow American experiences, namely to set up "whether provide service for peasants and low-income groups" as an assessment index.

As far as peasants who have a comparatively high income level are concerned, characteristics of finance exclusion are the lack of depth, accessibility and usability of finance service [13], which prevent peasants from improving their ability of self-development and negatively influence on the efficiency and financing sustainability of rural finance organizations. Principles of choosing governance tools should be the optimizing of environment, the attraction of large-scaled commercial banks, the designing of finance service for high-income peasants. Large-scaled commercial finance organizations have a stronger ability of risk identification and a larger amount of capital. They can better satisfy peasants' demand for finance service.

\section{Conclusions}

This paper follows the prevalent six dimension model of finance exclusion, makes a research on the rural finance exclusion from the angle of rural residents' livelihood, which approximately means the improvement of peasants' confidence and ability of self-development. With the method of structural questionnaire and open-end interviewing, our survey shows that physical exclusion in rural areas has been meliorated while non-physical exclusion, which includes access exclusion, condition exclusion, price exclusion, marketing exclusion and service exclusion, is still quite popular in rural areas. "Guanxi/background”, "rake-off/bribe" and other non-market factors exert a negative influence on the opportunity for both the low-income and high-income rural residents to get loans and other kind of finance services.

The essence of "non-physical exclusion" is the consequence of the lack of opportunity and ability of self-development in some regions and communities. The melioration of "physical exclusion" can be achieved by topdown institutional transitions, but this method does not apply to the governance of "non-physical exclusion", which has to be discussed in the frame of reciprocal causation between rural finance development and economic growth.

As a technical thesis, "governance of non-physical exclusion” should regard the satisfaction of peasants' self-development ability as its both prerequisite and purpose, choose governance tool with the concern of peasants' finance demand. The value of "governance of non-physical exclusion" should be sharing, coordinating, harmony, justice, poverty alleviation. Sex, age, income, ethnicity, residence regions, all these factors should not be the government's excuse to leave peasants and low-income groups excluded from finance service.

By using the criterion of annual "net income per capita", peasants can be divided into four parts: "severely poor", "barely out of poverty", "completely out of poverty" and "rich”. Each family has different finance demands so that finance exclusion they suffer from is different as well. It is important to pay enough attention to these differences because it is the key to understand the process of rural finance development and the prerequisite to choose governance tools. Whether to choose classic governance tools like government's direct providence and regulation or to use New Pubic Management tools like franchise operation, tax preference, allowance and the encouraging policy for loan increment, the government must take consideration of justice of finance service, sustainability of rural finance organization and the efficiency of investment in rural areas.

\section{References}

[1] Xiao, G. (2012) Beyond Left and Right Racialism. Zhejiang University Press, Zhejiang.

[2] Leyshon, A. and Thrift, N. (1993) The Restructuring of the UK Financial Services in the 1990s. Journal of Rural Studies, 9, 223-241. http://dx.doi.org/10.1016/0743-0167(93)90068-U

[3] Leyshon, A. and Thrift, N. (1996) Financial Exclusion and the Shifting Boundaries of the Financial System. Environment and Planning, 1150-1156.

[4] Leyshon, A. and Thrift, N. (1997) Inside/Outside: Geographies of Financial Inclusion and Exclusion in Britain. Working Paper, Nottingham University, Nottingham.

[5] Mayo, E. (1997) Policy Responses to Financial Exclusion. In: Rossiter, J., Ed., Financial Exclusion: Can Mutuality Fill the Gap? Working Paper, New Policy Institute, London, 12-15.

[6] Kempson, E. and Whyley, C. (1999) Understanding and Combating Financial Exclusion. Insurance Trends (The Association of British Insurers), 18-22.

[7] Financial Services Authority (FSA) (2000) In or out? Financial Exclusion: A Literature Research Review. Consumer 
Research Paper 3. FSA, London.

[8] Collard, S., Kempson, E. and Whyley, C. (2001) Tackling Financial Exclusion: An Area-Based Approach. The Policy Press, Bristol.

[9] Xu, S. and Tian, S. (2008) Finance Exclusion in Rural Areas of China. Journal of Financial Research, 195-206.

[10] Wang, X. and Qiu, Z. (2010) Rural Finance Exclusion: Practical Dilemma and Solving Strategies. Journal of Central University of Finance and Economics, 47-52.

[11] Gao, P. and Wang, X. (2011) Regional Difference and Influential Factors of Rural Finance Exclusion: An Empirical Study Based on Provincial Panel Data. Journal of Agro Technical, 93-102.

[12] Hu, Z., Yuan, L. and Liu, Y. (2012) Provincial Difference and Influential Factors of Rural Finance Exclusion in Chian. Journal of Shanxi University of Finance and Economics, 52-60.

[13] Li, C. and Jia, J. (2012) Finance Exclusion Level of China: A Construction and Calculation Based Finance Exclusion Index. Modern Economic Science, 9-15.

[14] Liu, L. (2008) Research on Rural Finance Development in China. Tsinghua University Press, Beijing, 27-35.

[15] Fei, X. (2002) The Chinese Native Soil Society. Peking University Press, Beijing, 9-27.

[16] Jianakoplos, N. and Bernasek, A. (1998) Are Women More Risk Averse? Economic Inquiry, 36, 620-630. http://dx.doi.org/10.1111/j.1465-7295.1998.tb01740.x

[17] Christiansen, C., Joensen, J. and Rangvid, J. (2010) The Effects of Marriage and Divorce on Financial Investments: Learning to Love or Hate Risk? CREATES Research Papers, School of Economics and Management, University of Aarhus, Aarhus. http://ideas.repec.org/p/aah/create/2010-57.html

[18] Guiso, L., Sapienza, P. and Zingales, L. (2003) People’s Opium? Religion and Economic Attitudes. Journal of Monetary Economics, 50, 255-282.

[19] Ameriks, J. and Zeldes, S. (2004) How Do Household Portfolio Shares Vary with Age? TIAA-CREF Working Paper, Columbia University, New York.

[20] Devlin, J. (2005) A Detailed Study of Financial Exclusion in the UK. Journal of Consumer Policy, 28, 75-108. http://dx.doi.org/10.1007/s10603-004-7313-y

[21] Sinclair, P.S. (2001) Financial Exclusion: An Introductory Survey. Centre for Research in Socially Inclusive Services (CRISIS), Heriot-Watt University, Edinburgh.

[22] Tian, S. (2007) Factors of Regional Difference of Finance Exclusion in China. Journal of Finance and Economics, 107-119.

[23] Zhu, L., Liu, G. and Li, X. (2010) Measurement and Analysis of Finance Exclusion in Central and Western China. Financial Theory \& Practice, 70-74. 
Scientific Research Publishing (SCIRP) is one of the largest Open Access journal publishers. It is currently publishing more than 200 open access, online, peer-reviewed journals covering a wide range of academic disciplines. SCIRP serves the worldwide academic communities and contributes to the progress and application of science with its publication.

Other selected journals from SCIRP are listed as below. Submit your manuscript to us via either submit@scirp.org or Online Submission Portal.
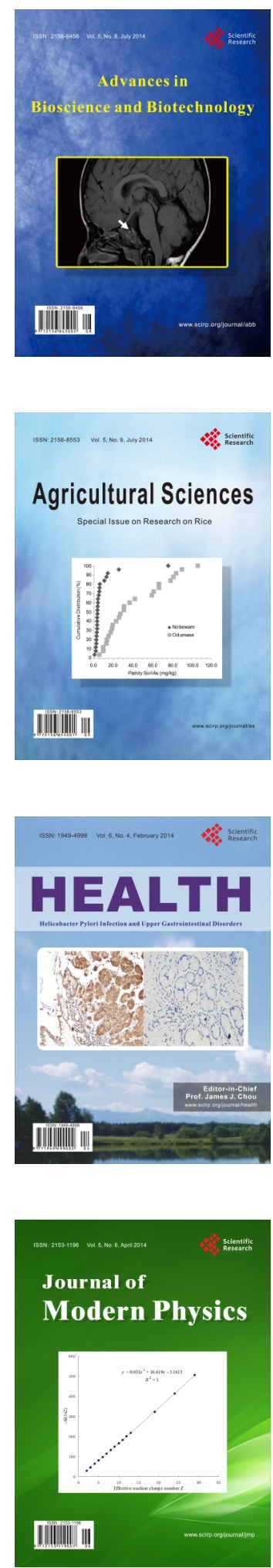
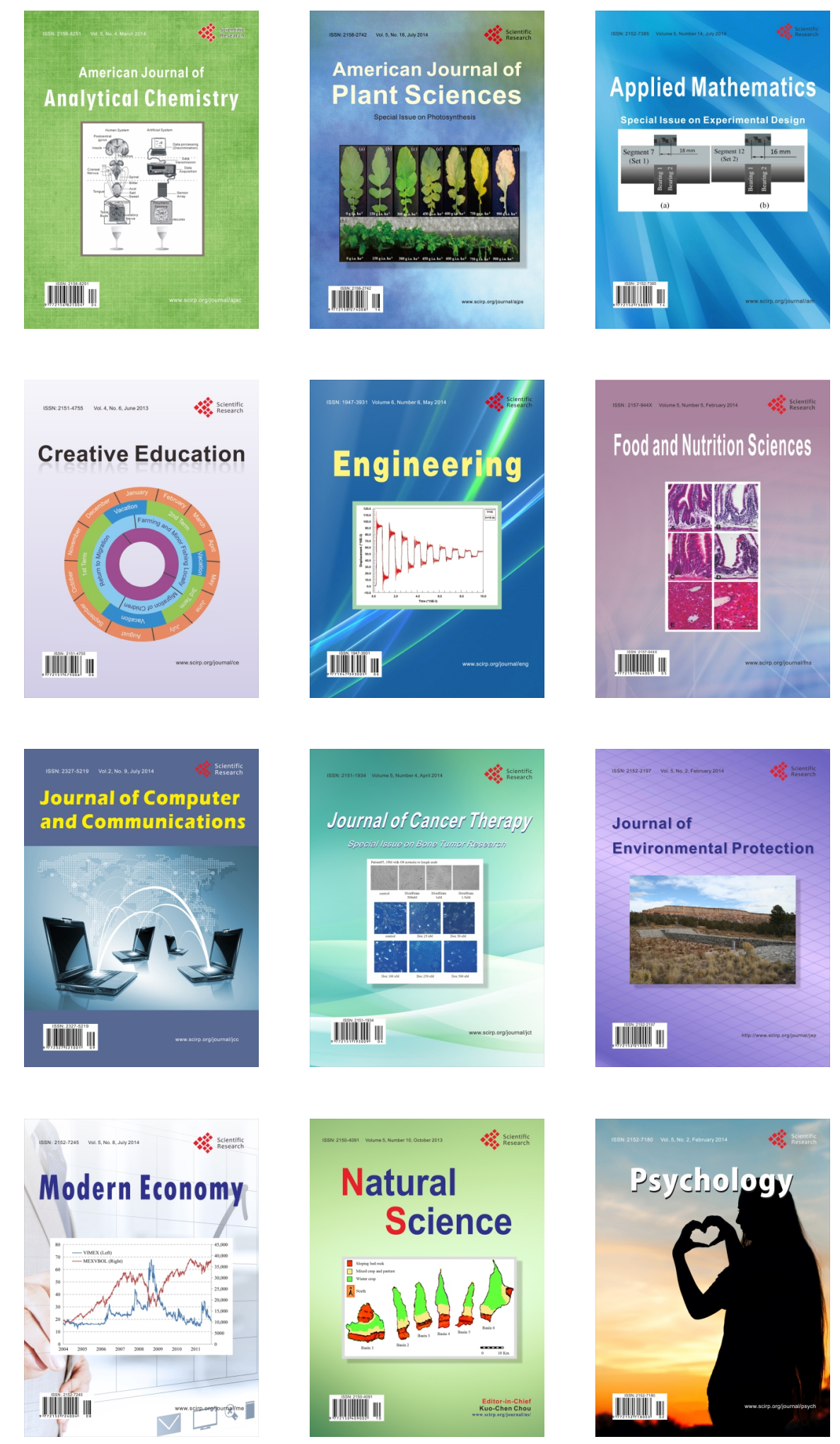